\title{
MEKANISME KOPING PADA PASIEN GAGAL GINJAL KRONIK YANG MENJALANI HEMODIALISIS DI UNIT HEMODIALISA RSUD BANDUNG
}

\author{
Angga Satria Pratama ${ }^{1}$, Andria Pragholapati², Ikhwan Nurrohman ${ }^{3}$ \\ 1,3Universitas Bhakti Kencana, Jl. Soekarno-Hatta No.754, Cipadung Kidul, Panyileukan, Bandung 40614, Jawa Barat \\ 2Universitas Pendidikan Indonesia, Jl. Dr. Setiabudhi No. 229 Bandung 40154, Jawa Barat
}

Email: angga.satria@bku.ac.id

\begin{abstract}
ABSTRAK
Gagal ginjal kronik merupakan gangguan renal yang progresif dan irreversible dimana kemampuan tubuh gagal mempertahankan metabolisme dan keseimbangan dan elektrolit, pasien gagal ginjal kronik harus menjalani terapi hemodialisis secara terus menerus seumur hidup dan akan menimbulkan masalah fisik dan psikologis yaitu depresi, pasien harus memiliki upaya dalam menyelesaikan masalah yang dihadapinnya yang dikenal dengan mekanisme koping. Tujuan penelitian untuk mengetahui mekanisme koping pada pasien gagal ginjal kronik yang menjalani terapi hemodialisis di unit hemodialisa Rumah Sakit Umum Daerah Kota Bandung.Metode penelitian menggunakan deskriptif kuantitatif. Sampel dalam penelitian ini menggunakan total sampling yaitu sebanyak 51 responden pasien gagal ginjal kronik yang menjalani terapi hemodialisis. Hasil penelitian mekanisme koping lebih dari setengahnya adalah mekanisme koping adaptif sebanyak 38 orang (74.5\%). Berdasarkan hasil penelitian Perawat di ruang hemodialisa diharapkan dapat meningkatkan asuhan keperawatan secara menyeluruh yang bukan hanya biologisnya saja tapi pada psikologis pasien gagal ginjal kronik juga, seperti memberikan konseling sehingga pasien mampu menggunakan mekanisme koping yang adaptif.
\end{abstract}

Kata Kunci: gagal ginjal; hemodialisis; mekanisme koping

\section{MECHANISM OF COPING IN CHRONIC KIDNEY FAILURE IN HEMODIALYSIS PATIENTS AT REGIONAL PUBLIC HOSPITAL OF BANDUNG}

\begin{abstract}
Chronic renal failure is a progressive and irreversible renal disorder in which the body's ability to fail to maintain metabolism and balance and electrolytes, patients with chronic renal failure must undergo continuous hemodialysis therapy for life and it will cause physical and psychological problems namely depression, patients must have the effort to resolve the problem that is facing by knowing the coping mechanism. The purpose of this study was to determine the coping mechanism in chronic kidney failure patients undergoing hemodialysis therapy in the hemodialysis unit of Regional Public Hospital of Bandung City. The research method used quantitative descriptive. The sample in this study used a total sampling of 51 respondents from chronic kidney failure patients undergoing hemodialysis therapy. The results of research on coping mechanisms more than half are adaptive coping mechanisms as many as 38 people (74.5\%). Based on the results of research Nurses in the hemodialysis room are expected to improve overall nursing care that is not only biologically but also psychologically in patients with chronic kidney failure, such as providing counseling so that patients are able to use adaptive coping mechanisms.
\end{abstract}

Keywords: kidney failure; hemodialysis; coping mechanism 


\section{LATAR BELAKANG}

Ginjal adalah bagian tubuh yang sangat penting. Fungsi ginjal sebagai penyaring darah dari sisasisa metabolisme menjadikan keberadaannya tidak bisa tergantikan oleh organ tubuh lainnya. Kerusakan atau gangguan pada ginjal menimbulkan masalah pada kemampuan dan kekuatan tubuh. Akibatnya, aktivitas kerja terganggu dan tubuh jadi mudah lelah dan lemas (Colvy, 2010).

Pusat data dan informasi perhimpunan Rumah Sakit Seluruh Indonesia (PDPERSI) juga menyatakan bahwa jumlah penyakit ginjal kronis \pm 50 orang per satu juta penduduk. Peningkatan tersebut dilihat dari jumlah klien yang menjalani hemodialisis pada tahun 2011 sebanyak 17259 orang dan terus meningkat di tahun 2012 sebanyak 22140 orang, tahun 2013 sebanyak 21759 orang, tahun 2014sebanyak 21165 orang, tahun 2015 sebanyak 30554 orang dan di tahun 2016meningkat tajam menjadi 52835 orang. Provinsi Jawa Barat adalah provinsi yang tertinggi dengan jumlah tindakan hemodialisis (Indonesia Renal Registry, 2016).

Penderita gagal ginjal kronik (GGK) memerlukan terapi yang bertujuan untuk menunjang kehidupanya yaitu terapi hemodialisis (HD) atau cangkok ginjal. Bagi pasien gagal ginjal kronik, terapi hemodialisis harus dilakukan seumur hidupnya (Muhammad, 2012). Hemodialisa adalah suatu metode terapi dialisis yang digunakan untuk mengeluarkan cairan dan produk limbah dari dalam tubuh ketika secara akurat atau secara progresif ginjal tidak mampu melaksanakan proses tersebut (Arif dan Kumala, 2011). Hemodilisis biasanya diprogramkan dua hingga tiga kali seminggu untuk gagal ginjal kronis. Hemodialisis lebih tepat untuk pasien dengan hemodinamis stabil yang dapat menoleransi perpindahan cairan yang lebih agresif dalam 3-4 jam dengan sekitar $300 \mathrm{~mL}$ darah dalam filter pada suatu waktu tertentu (Marlene, 2015).

Menurut Georgianni (2014), dalam penelitianya ditemukan bahwa dampak dari tindakan hemodialisis adalah dampak fisik (Anemia, nyeri, gangguan tulang) sedangkan dampak psikososial (depresi, penolakan penyakit, kecemasan, harga diri rendah, isolasi sosial, persepsi negatif daritubuh image/body, takut kecacatan, dan kematian, kehilangan pekerjaan, kesulitan keuangan).Pada kondisi yang memaksa seseorang untuk rutin menjalani hemodialisa dan ketidakpastian periode lamanya terapi tersebut dijalani merupakan stressor yang kuat untuk memicu terjadinya depresi. Selain itu, seorang pasien dengan gagal ginjal kronis juga masih menanggung pikiran tentang proses perjalanan penyakit yang dialaminya seperti, gejala-gejala yang ditimbulkan penyakit, komplikasi penyakit dan terapi dialisa, batasan makan dan minum yang merupakan bagian dari terapi, masalah finansial, psikologis dan psikososial (Pratiwi, 2013)

Saat seseorang berada dalam situasi yang terancam, maka respon koping perlu segera dibentuk. Mekanisme koping yang dapat diterapkan oleh individu yaitu mekanisme koping adaptif dan maladaptif (Stuart, 2016)).Mekanisme koping diartikan sebagai cara yang dilakukan individu dalam menyelesaikan masalah, menyesuaikan diri dengan perubahan serta respons terhadap situai yang mengancam Keliat (1999) dalam Jaya (2015). Sedangkan menurut Lazarus (1985) dalam Jaya (2015), koping adalah perubahan kognitif dan perilaku secara konstan dalam upaya untuk mengatasi tuntutan internal dan atau eksternal khusus yang melelahkan atau melebihi sumber individu.

Hasil wawancara yang dilakukan 12 april 2018 kepada 7 pasien mengatakan semuanya merasa menyesal dan kecewa karena di vonis gagal ginjal kronik dan harus menjalani terapi hemodialisis, pasien mengatakan sering merasa lelah dan lesu, dan terlihat lamban berbicara atau berpikir saat diwawancara oleh peneliti pasien juga mengatakan sulit tidur 5 orang mengatakan sedih (secara verbal atau non verbal dengan ekspresi muka sedih dan murung), merasa tidak nafsu makan, terlihat gugup serta gelisah, selanjutnya 2 dari 7 tersebut mengatakan sering menyendiri dan banyak tidur serta menonton tv dalam menghadapi permasalahan yang ada selama menjalani cuci darah (hemodialisis) dan 3 pasien lainnya mengatakan dengan makan banyak dan tarik nafas panjang. Pasien juga mengatakan saat ini mereka lebih banyak berserah diri kepada Allah Subhanahuwata A'la 
dan menganggap kondisinya saat ini adalah cobaan yang diberikan Allah berusaha untuk tetap sembuh dengan menjalani hemodialisis serta sering berbicara dengan pasien lain yang telah lama menjalani cuci darah dengan berbagi pengalaman selama menjalani cuci darah. Berdasarkan data diatas, penelitian ini dilakukan untuk mengetahui gambaran mekanisme koping pada pasien gagal ginjal kronik yang menjalani hemodialisis di unit hemodialisa RSUD Bandung.

\section{METODE}

Rancangan penelitian yang digunakan adalah deskriftif kuantitatif (Nursalam, 2016). Populasi dalam penelitian ini adalah semua pasien gagal ginjal kronik yang menjalani terapi hemodialisis rutin yaitu yang didapatkan dari unit hemodialisa Rumah Sakit Umum Daerah Kota Bandung sebanyak 51 pasien. Teknik sampel yang digunakan dalam penelitian ini yaitu sampling jenuh/total sampling yaitu teknik pengambilan sampel bila semua anggota populasi digunakan sebagai sampel yang berjumlah 51 orang. Instrumen yang digunakan menggunakan Coping dari Lazarus.

\section{HASIL}

Tabel 1 Distribusi frekuensi mekanisme koping pada pasien gagal ginjal kronik yang menjalani hemodialisis di Unit Hemodialisa RSUD Kota Bandung tahun 2018

\begin{tabular}{llll}
\hline No & Kategori & $\mathbf{f}$ & $\%$ \\
\hline 1 & Adaptif & 38 & 74.5 \\
2 & Maladaptif & 13 & $\mathbf{2 5 . 5}$ \\
\hline & Jumlah & $\mathbf{5 1}$ & $\mathbf{1 0 0}$ \\
\hline
\end{tabular}

Berdasarkan tabel 1 diatas menjelaskan gambaran mekanisme koping pada pasien gagal ginjal kronik yang menjalani terapi hemodialisi di unit hemodialisa RSUD Kota Bandung lebih dari setengahnya adalah mekanisme koping adaptif yaitu sebanyak 38 orang(74.5\%).

\section{PEMBAHASAN}

Gambaran mekanisme koping pada pasien gagal ginjal kronik yang menjalani terapi hemodialisi di unit hemodialisa RSUD Kota
Bandung lebih dari setengahnya adalah mekanisme koping adaptif yaitu sebanyak 38 orang (74.5\%), dan sementara itu sebagian kecil pasien menggunakan mekanisme koping maladaptif yaitu sebanyak 13 orang (25.5\%). Banyaknya klien yang menggunakan mekanisme koping adaptif pada umumnya pasien sudah mengalami hemodialisis berulang kali sehingga sudah menjadi pola dalam kehidupanya (Mutoharoh, 2010).

Berdasarkan hasil penelitian disebutkan bahwa mekanisme koping yang adaptif dilakukan dengan menerima seberat apapun hemodialisis pasien harus menghadapinya, membicarakan masalah dengan keluarga, berdoa dan berdzikir, mencoba menyelesaikan masalah secara bertahap. Hal ini sejalan dengan penelitian Armiyanti, Rahayu (2013) dengan judul faktor yang berkorelasi terhadap mekanisme koping Pasien CKD yang menjalani hemodialisis di RSUD Kota Semarang. Hasil berdasarkan kuesioner mekanisme koping yang adaptif yang paling banyak digunakan oleh pasien adalah mencoba berbicara dengan orang lain, mencoba mencari informasi yang lebih banyak tentang masalah yang sedang dihadapi, menghubungkan situasi atau masalah yang dihadapi dengan melakukan kegiatan ibadah dan berdoa, melakukan latihan fisik untuk mengurangi ketegangan, membuat berbagai alternatif tindakan untukmengurangi situasi, dan mengambil pelajaran atau pengalaman masa lalu.

Mekanisme koping adalah tiap upaya yang diajukan untuk penatalaksanaan stress, termasuk upaya penyelesaian masalah langsung dan mekanisme pertahanan ego yang digunakan untuk melindungi diri (Stuart, 2016). Mekanisme koping adaptif yang banyak dipilih adalah berdoa, berserah diri pada Allah dan menerima seberat apapun hemodialisis pasien harus menghadapinya. Hasil penelitian tentang mekanisme koping yang adaptif sejalan dengan penelitian Novalia (2011) dengan judul koping pasien gagal ginjal kronik yang menjalani hemodialisis di RSU Adam Malik Medan yang menunjukan bahwa koping yang paling sering digunakan pasien hemodialisis adalah sprirtual. $\mathrm{Hal}$ ini tidak sejalan dengan penelitian yang dilakukan oleh Yemima, Kanine, dan Wowling 
(2013) dengan judul mekanisme koping pada Pasien gagal ginjal kronik yang menjalani terapi hemodialisis di RS Prof.Dr. R. D. Kandou Manado, hasil penelitian menunjukan lebih banyak pasien gagal ginjal kronik yang menjalani terapi hemodialisis menggunakan mekanisme koping maladaptif, hal ini disebabkan oleh berbagai hal yang berpengaruh terhadap kondisi pasien yang ada, baik psikis maupun fisiknya. Pikiran yang optimis dapat membuat keadaan yang stresful sebagai sesuatu hal yang harus dihadapi dan diselesaikan, oleh karena itu individu akan memilih menyelesaikan masalah yang ada dibandingkan dengan individu yang mempunyai pikiran yang psimis (Matthews 2008). Banyak reaksi emosional yang dialami oleh pasien gagal ginjal kronik yang menjalani hemodialisis dan mengharuskan pasien tersebut bereaksi dan mengatasi masalah yang dialaminya dengan menggunakan mekanisme koping yang ada dalam dirinya (Tharob, 2014).

\section{KESIMPULAN DAN SARAN}

Sebagian besar responden yaitu pasien gagal ginjal kronik yang menjalani terapi hemodialisis di unit hemodialisa RSUD Kota Bandung tahun 2018 menggunakan mekanisme koping adaptif. Perlu adanya eksplore yang lebih dalam pada responden hemodialisis dengan menggunakan sampel yang lebih banyak dan lama waktu dilakukan hemodialisa.

\section{REFFERENSI}

Arif \& Kumala. (2011). Asuhan Keperawatan Gangguan Sistem Perkemihan. Jakarta : Salemba Medika.

Armiyanti. Y , Rahayu. D. A. (2014). Faktor yang berkorelasi terhadap mekanisme koping Pasien CKD yang menjalani Hemodialisis Di RSUD Kota Semarang.

Colvy Jack. (2010). Gagal Ginjal (Tips Cerdas Mengenali \& Mencegah Gagal Ginjal). Yogyakarta : DAFA Publishing.

Georgianni, S \& Babatsikou, P. (2014). Psychological Aspects in Chronic Renal Failure. Health Sciance Journal.
Indonesian Renal Registry, (2016), 9th Report Of Indonesian Renal Registry. https://www.indonesianrenalregistry.org.

Jaya K. (2015). Keperawatan Jiwa. Tanggerang : Binarupa Askara Publisher

Marlene, H. (2015). Belajar Mudah Keperawatan Medikal-Bedah Vol 1. EGC: Jakarta.

Matthews, Ellyn E and Cook, Paul F. (2008). Relathionship Among Optimism, WellBeing, Self Transcedence, Coping, And Social Support In Women During Treatment For Breast Cancer. Journal Of Pshycho-Oncology 12 : 716-726

Muhammad, A. (2012). Serba Serbi Gagal Ginjal. Yogjakarta: DIVA Press. KARISMA Publishing Group.

Mutoharoh, I. (2010). Faktor-faktor yang berhubungan dengan mekanisme koping klien gagal ginjal kronik yang menjalani terapi hemodialisis di rumah sakit umum pusat (RSUP) Fatmawati Tahun 2009.

Novalia, E. (2011). Koping pasien gagal ginjal kronik yang menjalani hemodialisis di RSU Adam Malik Medan.

Nursalam, N. I. D. N. (2016). Metodologi Penelitian Ilmu Keperawatan.

Pratiwi, D.T. (2013). Hubungan dukungan keluarga dengan tingkat depresi Pasien Gagal Ginjal Kronik yang menjalani Hemodialisa di Ptpn X Rumah Sakit Gatoel Mojokerto.

Stuart. W.G. (2016). Praktik dan Prinsip Keperawatan Kesehatan Jiwa. Singapoer : Elsevier. (Terjemahan Budi Anna Keliat dan Jesika Pasaribu).

Tharob, I. (2014). Hubungan dukungan keluarga terhadap mekanisme koping pada Pasien Gagal Ginjal Kronik dengan hemodialisis di RSPAD Gatot Soebroto Jakarta.

Yemima. Wurara, Kanine. E., Wowling. F. (2013). Mekanisme koping pada Pasien Gagal Ginjal Kronik yang menjalani terapi hemodialisis di RS Prof.Dr.R.D. Kandou Manado. 